\title{
学会賞受賞講演
}

\section{Polymer Rheology and Rheo-Optics}

by

Shigeharu ONOGI

Matsue College of Technology, 14-4 Nishi-ikuma, Matsue, Shimane 690

\section{高分子レオロジー及びレオ・オプティクス}

\author{
小野木重 治*
}

(原稿受理：1986年 9 月10日)

研究の第一線を退いて早や 2 年を経過したが, 今にして大学卒 業後40年間にわたる京都大学時代を振り返ると, いろいろな出来 事があり，自分であいろんなととをしてきたあのだと不思議にさ え感じられる. 特に, 戦中 · 戦後の想像を絶する混乱と欠乏の時 代に，科学者にとって最屯重要な20才，30才台の時期を過でし， さらにようやくその時代を乗り越えて曙光が見えかけたとてろで 学園紛争に遭遇し, 貴重な時間とエネルギーを浪費し, 神経をす りへらした。 そんな境遇の中でも研究に対する意欲だけは失わな いようにと懸命に踏ん張ってきたものの，いかんせん制動が強す

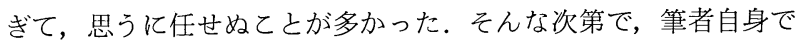
は学会賞に值するような立派な業績をあげることはできなかった ように思われるのであるが，乙のたび虑らずあ受賞の栄に浴し恐 縮至極に存じている。

\section{粘弾性研究の端緒}

さて, 筆者のレオロジーに関する研究は, 終戦後間むなく紙や パルプシートの弾性を測定した時に始まる。それまでは戦時研究 の一端として, クロルナフタリンを対象にして誘電体の研究を行 っていた1)のであるが，終戦を契機に繊維関係の研究に転向する こととなり, 指導教授であった堀尾正雄先生のご指示に従って, 紙のかたさについて研究を始めた。

紙の曲げかたさ $E I$ または弾性率 $E$ 簡単に測定できる方法は 無い屯のかと, 電気工学や物理学教室の図書室へ毎日のように出 掛けて文献をあさっているうちに，D.A. Oliver (1932) という 人が振動法で紙の曲げかたさを測定した報文にぶつかった ${ }^{2)}$.て の方法を採用するに限ると決断したのであるが，当時てれに使え るような可聴周波領域の可変周波発振器は市販されておらず, 苦 労の末やっとナショナルの試作 1 号機を入手したてとを覚えてい る.

\footnotetext{
* 松江工業高等専門学校 $\overline{7} 690$ 松江市西生馬町 $14-4$
}

Oliver の測定法は，いわゆる振動リード法 (vibrating reed method) であるが，乙机で紙の動的曲げ弾性率を測定している 間に, 紙の種類によって共振曲線の形に著しい差異があり, それ に伴って紙の手ざわりが異なることに気付いた. 当時, 固体の粘 弾性とか粘性について明確な概念をあっていたわけではないが, 一般的には無視されているけれぞあ弾性率と同様に紙の本質を表 す重要な別の量があり, 乙れが共振曲線の解析にようて求められ るのではないかと考えた。 そんなととを念頭において, 例えば振 動論の本を読めば, 自分が考えている量は内部摩擦之書かれてい る量にあたると思われた。そこで, 弾性と内部摩擦を有する梁 （はり）のたわみ振動の微分方程式を解き, 共振々動数と band width とから弾性率と内部摩擦係数を求める近似解を得た ${ }^{3)}$. そ の前後に判明したことであるが，主としてアメリカで戦中から戦 後にかけて，ゴムや繊維などの粘弾性に関する研究が活発に行わ れ，上の内部摩擦は粘性として取り扱われていた。

この振動リード法を使って, 紙年のほか種々の高分子フィルム5) や単繊維6)の粘弾性を測定し, 多くの知兒が得られたのであるが, なかんずく, 結晶性高分子と無定形高分子とでは, 粘弾性の周波 数及び温度依存性に著しい相違があり，それらの微細構造の差異 によって変形機構む本質的に相違することを思わせた。これが後 年, 結晶性高分子のレオ・オプティクスの研究を㕸めさせた原因 である。

\section{高分子濃厚系の粘弾性}

高分子の固体について研究する一方で，濃厚溶液や溶融物の粘 弾性をぜひ測定してみたいという強い願望をむっていた。 1950年 頃には高分子溶液の电糸性が多くの研究者の興味をひき，曳系性 には粘性のほかに弾性む関係しているのではないかとの示唆はな されていたが, 粘弾性の測定結果, 特にタイムスケールの広い箶 囲にわたるデーターは皆無であったから，議論はあまり進展しな 
汃った。その頃アメリカでは, J.D. Ferry (1949）が電磁変換 器法を開発して, 高分子準濃厚溶液の可聴周波領域における粘弾 性を測定した報文を発表した7). 彼らの研究結果によれば, 高分 子濃厚溶液は可聴周波領域においてさえ大きな弾性率を有するこ とが明らかであったから，纎維の紡系液について粘弾性を测定し， その結果と可紡性とを関係づけたいという思いは, いっそう強く なった。

しかし, 電磁変換器の装置を作るのに必要な電気機器類は高価 であるため, とてあ一度に購入するだけの研究費はなく, 毎年一 つ, 二つと買い進めた, そうこうするうちに, 当時旭化成に入社さ れて間のなかった平井英史氏 (現東大教授) が研究生として来ら れ,一緒に紡系液の粘弾性について研究するとととなった。それは 1952年のととであったと思う。氏は装置を製作し，ポリビニルア ル:コール水溶液とビスコースの粘弾性を精力的に测定された 8 ,9). この研究は, わが国で高分子濃厚溶液の可聴問波領域における動 的粘弾性を測定した最初のものであろう.

ポリビニルアルコール溶液の粘弾性の測定は, その後, 浜名伊 佐夫氏が引き継ぎ，装置にあねじり振動レオメーターが追加され $た^{10)}$. これら一連の研究によって, 高分子濃厚溶液の粘弾性の周 波数依存性が温度のみならず, 高分子の分子量と濃度に屯強く依 存すること, 高分子隂厚溶液の最長緩和時間は Bueche や Rouse の分子論から予測される值に比べてはるかに大きいこと, 粘弾性 の周波数依存性は分子量分布に屯大きく影響されることなど，い くつかの新事実を見いだした，乙のときの論文 ${ }^{10)}$ では, 分子量分 布の影響之言ってあ, 平均分子量の異なる 2 種の試料をブレンド したあのについてのデーターしか得られていなかったが，ブレン ドの粘弾性曲線は明らかに成分のそれ之傾向が異なり, 当時来日 していた H. Leaderman はての事実に非常な興味を示した。後 年 (1964), ポリエチレンの溶融物についてより詳細な研究結果 を発表したとき11,12), 彼は分子量分布の問題が氷解したと喜びの 手紙を送ってきたが，それは彼の逝去の直前のととであり，恐ら くこの手紙は彼の絶筆だったのではないかと思っている.

さて, 濃厚溶液が示す高い弾性率之粘度あるいは長い最長緩和 時間は，分子間の “からみ合い”によるあのであり，しかもこの “加み合い”は分子量と濃度によって決定されるむののように 感知し，その後しばらくこの問題と取り組んだ。しかし，当時は “からみ合い”之言って屯, その概念は全く混沌としており, か らみ合いに対して多くの人達が描いていたピクチュアは, 分子が 位相幾何学的もつれによって接合した，どちらかと言えば網目構 造に近いあのであった，そんな中で筆沓らが得た結論は，非摂動 鎖に近い広がりをもった分子が, 初めて詰まった状態に達する点 が臨界分子量または臨界濃度であり, これらの点を越えて, いわ ゆる “からみ合い領域”に入れば，分子は互いに重なり合いはす るが，依然として流動単位であるということであった。さらに， からみ合いを決定する分子量 $M$ と濃度 $c$ との関係は, 臨界点にお いて

$$
c M^{\beta / \alpha}=\text { const. }(\alpha, \beta \text { は定数 })
$$

となり，溶液によって $\beta / \alpha$ は $0.5 〜 0.74$ となるととを見いだし $た^{13,14)}$.

上に述べた電磁変換器法は, 測定に苦労を要する割には精度が 低く，また高温における測定に適さないため, 溶融物についての 測定は不可能であった。さらに，低周波用に製作したねじり振動
レオメーターも，外筒および内筒の振動を光学的に記録する不便 さがあり, 測定温度む $100^{\circ} \mathrm{C}$ ま゙は上げられなかった。そてで, 濃厚溶液と溶融物の耑方に使えて, しか屯扱いやすくて精度の高 い二重门简型のレオメーターを試作した ${ }^{15)}$. 内筒の振動は, 差動 トシンスを初めて使用することによって, 外筒の振動と共に電気 的に記録する方式を採用し，また駆動部の簡単な切換で，外筒を 一方向に回転させるばかりでなく，一定振幅のねじり振動を与え るととあでき, その回転数と振動数は, 高くはないが広い範团に 変えられるようにした，乙のレオメーターは，筆者らの研究を大 いに促進したにとどまらず，乙れと同型または改良型が多くの場 所で使用されたそとの前に試作した自記記録式工栄用粘度計16)之 共に, 高分子濃厚系のレオロジーと工業に, さらには同種レオメ ーターのその後の発展に大きく寄与したあのと自負している.

上に述べたように, 濃厚溶液の研究は, 粘弾性に及ぼす分子量 とその分布, 濃度, 温度などの影響を中心に進められ, その後の 溶融物の研究屯同様の線に沿って行われたが, 分子量と分子量分 布（または混合）の影響は，1960年代終期から升田利更郎君らが 単分散ポリマーで分子量が異なるあの多数を合成して試料として 用いるようになってから，いっそう明確になってきた．また，単 分散枝分かれポリスチレンを使った一連の研究によって, 線状高 分子之枝分かれ高分子との本質的な差買, 基本的なレオロジ一的 パラメーターに及ぼす枝分かれの種類, 枝の数と長さの影響など が追々と明らかになってきた。 乙れらの研究結果は, 升田君が有 功賞を受賞したときの対象となったものである ${ }^{17)}$.

\section{懸濁液のレオロジー}

眯濁液のレオロジーの研究を始めたのは, 確か1965年のととで

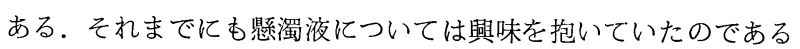
が，例えば高分子またはその溶液に固体粒子を分散させた係は， レオロジー的には最む複雑な系の一つと考えられた。 また1940年 代からは，懸溜液のレオロジー的研究に見るべきものがないとと を考える之，たとえ研究を始めたとしてあ泥沼に足を突っ込む乙 とになるのではないかという警戒心が強くはたらいた。事実，そ の頃すでに懸濁液の粘弾性を測定した結果の報告むあったが，そ れを進展させることは容易でないように思われた。 また，かつて 前節に述べたレオメーターを製作した直後に，化粧用クリームに ついて外筒之内筒との振幅のリサジュー図形を描かせたところ, 普通の（線形性の）液体の場合と異なり, 図形は楕円形から著し く丕んだあのとなり，線形性液体に対する方法で解析することは, とうてい不可能であった. とうぜん, 非線形粘弾性体としての解 析が必要であったが, 当時その方法は無かったし, 自分でそれを 鬥発する余裕が無かったというより，むしろ避けていた。

それにあかかわらず賏濁液の研究を手掛けたのは, 二つの理由 による. 一つは, 1965年に松本孝芳君が大学院に入学して筆者ら の研究室に入ってきたが, 彼の出身を考えて, 印刷インキとかぺ イントと関連の深い分散系のレオロジーについての研究をすすめ たことである. あう一つの理由は, 製紙会社の工場長であった後 簐の一人から, 紙のコーティングと関連して䀣濁液のレオロジー

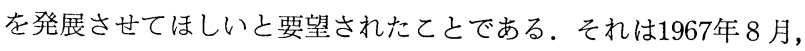
北海道大学でレオロジー討論会が開催された時のととであった。 討論会終了後ぜひ工場へ来てほしいという国策パルプ侏勇払工場 長の招請を受け，コーティングの現場を見せてもらったが，コー 
ティングには時どき原因不明の不調が起きて困るということであ った，不調の原因は，機械よりはむしろコーティング剤にあるよ うだが, そのレオロジーてついては不明なので, ぜひ大学で研究 を進めてほしいとの依頼を受けた。 その後, 直接コーティング剂 を使って研究することはしなかったが, 獎濁液一般の粘弾性につ いて本格的な研究を進めることにした。

松本君のその当時加らの研究業績屯, 昨年度の有功賞の対象之 なったものであるから ${ }^{18)}$, その内容についてはで存知の方が多い ことと思うが，興味深いいくつかの新事実が明らかにされた。な かんずく，筆者ら㤂第二平坦領域 (second plateau) と命名し た, 懸濁液特有の緩和領域が多くの場合に現れること, この領域 で動的粘弾性が著しく非線形になるととの発見は重要であった ${ }^{19)}$.

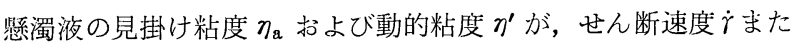
は角周波数 $\omega$ の低い領域でゼロせん断粘度 $\eta_{0}$ を示すことなく増 大し, 睁蔵剛性率 $G^{\prime}$ や損失剛性率 $G^{\prime \prime}$ がこの領域で平坦化の傾向 を示すことは, 筆者らの研究以前に屯幾人かの研究者によって見 いだされていた。しかし，第二平坦領域がさらにタイムスケール の長い領域でどうなるか一笑際には，例えば架橋ポリスチレン 球状粒子の懸濁液では， $G^{\prime}$ および $G^{\prime \prime}$ が高分子の流件領域におけ るように再び低下する——含ひて, 第二平坦領域の意義, すな わち，乙れが分散粒子がつくる凝集構造の緩和に基づくあのであ って, 粒子間相互作用を変えることによって出現したり消失した りするあのであることを明らかにしたのは，筆者らが最初である と信じる。

化粧用クリームの動的粘弾性が，低周波領域で著しく非線形性 であるととを前述したが, 一般の懸濁液の粘弾性屯第二平坦領域 で著しく非線形性となる。 その解析法についても, 松本君らが研 究した ${ }^{20,21)}$.

\section{長 時 間 緩 和}

高分子濃厚系の粘弾性を, ふつうの温度及びタイムスケールで 測定すれば, 主として流動領域 (flow region)または終端域 (terminal zone) と呼ばれる領域と, ゴム状平坦領域 (rubbery region) の闭方または一方が観测される. 分子量が臨界分子量 $M_{\mathrm{C}}$ 以上である限り, その影響が現れるのはてれら二つの領域におい てであることが，すでに1950年代から明らかにされていたが22,23)， 分子量分布や枝分加れの影響が現れるのも，乙れらの領域におい てである，高分子濃厚系に古体粒子が比較的大量に分散した濃厚 懸濁液では, 上記の流動領域より長いタイムスケールの領域に, 分散粒子がつくる凝集構造の緩和に基因する第二平坦領域が現れ る.したがって, 筆者らが過去 20 年余にわたって行ってきた高分 子濃厚系及び眯濁液の粘弾性に関する研究は, すべて高分子の加 らみ合い構造及び分散粒子がつくる凝集構造の長時間緩和の研究 としてまとめるととができよう.

通常の無定形高分子について, 広範囲のタイムスケールにわた る緩和スペクトルを眺めると, 短時間領域に, サブモレキュール の平均緩和時間に相当するタイムスケールに一つのピークがあ る. このピークの存在は, 1950年代吩ら知られていたが, その頃 から長時間領域のスペクトルは箱型であると言われてきた ${ }^{24)}$.し かし, 単分散高分子の実験結果は, ゴム状領域から流動領域へ移 り変る領域に，分子のからみ合い構造の緩和時間に相当するタイ ムスケールに別のピークが明らかに存在するととを示す ${ }^{25)} .1951$
年に Journal of Applied Physics 飞発䒾した論文 ${ }^{5}$ に，セルロ 一ス系高分子の粘弾性を㳎い周波数範囲にわたって測定すれば, 損失弾性率に二つのピークが現れるにちがいないと予告したのが， 約20年経過して，物質てそちがっていたあのの，事害であること が確認されたのは，てのうえない喜びであった。

奬濁液にみられる第二平坦領域の存在は，粘弾性の分野では新 しい発見と言えるであろうが，ここでの弾性率の分散は，誘電体 の分野で古くから界面分極または Wagner 分極として知られて いる分散現象江匹敵すると考えてよいよう纪思う。界面分極が， 複層系, 分散系などにみられる特有の分極であるよう亿, 第二平 坦領域屯分散系で親測される。

\section{結晶性高分子のレオ・オプティクス}

筆者が京都大学で所属した教室は, 1960年度までは繊維化学教 室で, 1961年度から現在の高分子化学教室に改組された. 乙の改 組前には, 研究のテーマとか対象を選ぶにあたっては, まず繊維 之その工業に関係の深いあのへ之頭が働いた。 それゆえ，高分子 を選ぶにしても，無定形高分子よりは結晶性高分子が優先され た．乙の結晶性高分子を重視する傾向は筆者らに之どまらず，あ っと全国的なあのであったように思う。，それは，当時わが国の繊 維工業が工業全体の中で重要な地位を占めていたからである．高 分子の粘弾性の研究を歷史的に振り返ってみても, 米国ではエラ ストマーその他の無定形高分子の研究が多かったのに対し, 日本 では繊維を中心とする結晶性高分子の研究が多かった。

結晶性高分子, 特に高結晶化度を有して絨維に適するような高 分子の粘弾性挙動を, 無定形高分子のそれと比較すれば, 温度及 びタイムスケール依存性の点で, きわめて顕著に相違するてとに 気付く。乙ういった顕著な相違が両者の微細構造, したがって変 形機構の本質的な差異に基因するあのであろうことは，今日では きわめて常識的牦解釈されると乙ろであるが，1950年代後半まで はそうでなかった。例えば，結晶性高分子の緩和スペクトルが平 坦である（弾性率の周波数依存性が少ない）のは，その分子鎖が 剛いためであろうと考え，分子論的にそれを証明しようとする理

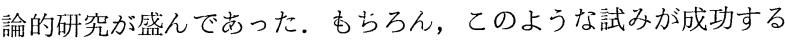
はずはなかった。

そんな中で筆者は, 結晶性高分子については結晶領域之無定形 領域の運動（配向）あるいは緩和を，領域ごとに別々にとらえう る新しい研究法の開発が必要であろうことを感じ，また説いてき セ.マサチューセッツ大学の Richard S. Stein 教授から河合弘 廸教授の後継者として留学しないかと誘われたのは，ちょうどそ 几ふ時（1960年春）であった，何回か亿わたって手紙を交換し， 研究のテーマと付容について相談を重ねた結果, 結晶性高分子を 研究する新しいう法としてまず動的複屈折の研究を行うことに決 定し，vibrator を京都で設計・製作して送るとととし，その完成 を待たずに10月終り頃に出国した.

マサチューセッッ大学の所在地アーマストへは, 当時 MIT K 留学しておられた倉田道夫教授にボストン空港から送っていただ いて10月末日に到着し, 翌11月 1 日から大学へ出勤した. 当時, Stein 教授の研究室は少人数の小規模な存在であったが, きわめ て家族的で，和やかな雾囲気をもっていた。また，アーマストは 人口 1 万余の小さい町であった（現在の人口は倍以上になってい る）が，昔から日本との関係が深いため, 町民は非常に親日的で 
あった。そんな訳で，アーマストに狲ける研究生活は，しでく快 適なあのであった。

日本からの vibrator が到着する前に，電動鋸の振動装置を利 用して高分子フィルムに振動を与えうる装置と, 複屈折を透過法 で測定できる光学系を組み合わせた簡単な装置を製作し，予储実 験を開始した。低密度ポリエチレンの複屈折が, 振動数と共に低 下する現象を初めて觀祭したのは，約 1 カ月後のと之であった 研究室の全員がそれを知って, “Congratulations”在連発して韾 んでくれた，あの時の感激は，今も忘れることができない，後で 考えれば，てのとき試料として低密度ポリエチレンを選んだのは， 大きな幸運であった。たまたま実験台の上に誰が何に使用したの か判ら妨エチレンフィルムのロールが転がっているのを試料 として使ったのであるが，もし，ほふの物質を使用してお扎ば， 複属新の変化は小さいので, 簡単には测定できず, その後の研究 の進捗にも影響していたように思われる。

しかしながら，幸運の直後に不運が訪れた．12月下旬に到着す る予定で日本から出荷された vibrator が行方不明になったので ある. 航空会社で調查した結果, ニューヨークまで来ていたとと は確かであるが，その後杳として行方不明になってしまった．念 遽 2 台目を製作して送り直してもらったが，それがために約半年 の損をした。

アメリカにおける研究生活は, 正味 1 年 5 カ月間であったが, 動的複屈新の研究に専念するほか, 機会があれば学会に出席し, また Stein 教授について多くの大学や会社の研究所を歴訪した. そうすることによって，多くの友人，知人をつくることができた が，それがその後の国際交流に大きく役立った・

1962年 4 月に帰国してからは，浅田忠裕，田中皓，福朴势治君

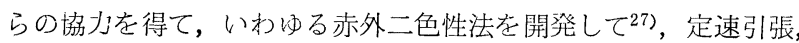
及び応力緩和の測定に伴う赤外二色比の時間的変化を追跡するほ か, 複屈折や二色性の変化を測定できる装置屯製作し，ポリエチ レンを始めとする結晶性高分子の変形機構の解明に努めた。 よく 知られているように，結晶性高分子のフィルムに変形を与えた之 きの複屈折は, 結晶領域における分子配向 (結晶配向) の笴与之 無定形領域に新けるそ礼（無定班配向）との和であり，二色比は 染料が固定されると考えられる無定形領域の分子配向之関係す る. 赤外二色比を利用するときには，適当な結晶バンドと非晶バ ンドが存在しさえすれば，両領域の分子配向を独立比知ることが できる。したがって，これらの方法を適当に組み合わせることに よって, 結晶領域からの寄与と無定形領域からの寄与とを分離す ることができる訳である。実際に，応力緩和過程のポリエチレン について, てのような分離に成功したのは ${ }^{28)}$, 初めて動的複屈折 の研究を始めてふら約10年後のととであった。

\section{その他の系のレオ・オプティクス}

上述べた亦外二色性法は，異種高分子のブレンド，例えばポ リエチレンとポリプロピレンとの混合物のフィルムに变形を与え たときの各成分の配向を知るために, あるいはブロック共重合体 フィルムに変形を加えたときに，各成分ブロックの両方または一 方がいかに配向するかを知るため亿利用することができる。 それ は，ブレンドの成分あるいはブロック共重合体の成分ブロックに 特有のバンドの二色比は, 他成分の混合または共重合によって影 響されること方ないからである27)。
以上，レオ・オプティクスの高分子フィルムへの応用について 述べてきたが，もちろん流動性を有する物質に応用するてとむで きる，浅田君らは，低分子扰よび高分子液晶に一定のせん断速度 を与えて流動させるとき，あるいは流動を停止させるとき亿起と る構造・組織の变化を追跡するため，円錐-円板型粘度計と光学 系とを組み合わせた測定装置を製作した，光学系の一つとしては 分光光度計を用い，吸収スペクトルの変化を測定する ${ }^{29)}$ 。むう一 つの光学系は, 複屈折の測定に使われるると同じょうな系で, 偏 光子と倹光子の光軸の方向を流動方何に対していろいろ変えて透 過光強度を測定する ${ }^{30)}$. これらの光学量が液晶の構造・組織に関 する情報を提供してくれるわけである。なお, 粘度計の円錐, 円 板は，光を透過させるために，特別に石英で作らてている。

てのような測定装置を使って種々のせん断速度学飞打ける見掛 け粘度 $\eta_{\mathrm{a}}$ を测定した結果, $\eta_{\mathrm{a}}-\dot{\gamma}$ 曲線は一般に三つの領域をつ くることが判明した ${ }^{31)}$. すなわち, $\dot{\gamma}$ の低い領域では $\eta_{\mathrm{a}}$ は $\dot{\gamma} の$ 低下と共に増大する。乙礼は, 眯濁液の第二平坦部に相当する挙

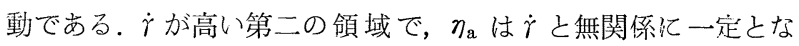
り, ニュートン的である. $\dot{\gamma}$ がさらに高い第三の領域で, $\eta_{\mathrm{a}}$ は $\dot{\gamma}$ と其に低下するが，低下率は高分子溶液などに比べて非常に小さ い. 浅田君らは, これら三つの領域で, 液晶がポリドメイン系 一崩䬉したポリドメイン系—モノドメイン連続相に変化する 之解釈している.

この一例からあわかるように，レオ・オプティクスは，結晶性 高分子の複雑な変形機構の解明に大きく貢献したように，それに 劣らず複雑な構造・組織を有する液晶が流動中に，あるいは流動 を停止した後に示す構造・組織の変化について, 有用な知㒻を与 えるようである. かつて本学会の創立10周年記念講演の中で, J.D. Ferry 教授は, レオロジー的研究というのは, 他の方法に よって物質構造に関する情報が充分に得られていて, 力学的挙動 に分子諭的解瀵を与えうるときにだけ大きな価值を発揮できると いう意味のととを述べられたが32)，レオ・オプティクスは正にそ の一例であるように思われる。

レオ・オプティクスは, また高分子の構造研究に一つの新しい 万问を与えた点で高く評価されると思う. 上に述べた複屈折, 亦 外二色性を始め, $\mathrm{X}$ 線回折, 光散乱などの測定は, 従来すべて平 衡状態にある試料に可視光, 赤外線, X線などを入射して行われ たのであるが，レオ・オプティクスではマクロ的あるいはミクロ 的行動いている試料敒電磁波を入射して，その效果がタイムスケ 一ル（時間または周波数）の関数として頡測される。したがって， 構造そのあのについての知見だけでなく, 構造の運動についての 知見も与えてくれる訳である。乙のように，今までは時間之無関 係であると考えられてきた過程を, タイムスケールを導入して 追跡する方法は，今後ほかの分野であ增えていくのではなからう 加.

\section{お わり に}

以上が高分子のレオロジーとレオ・オプティクスの分野で行っ てきた研究の主流れであるが，もとあ之筆者はてのような研究 だけに終始するつもりではなかった。 むしろ, てれらの研究で得 られた知見を役立てて, 新しい高分子材料あるいは優礼た高分子 材料を開発してみたいと思っていた。学部での講義を, ずっと高 分子材料学で押し通したのあ, 実はこのような気持が強かったか 
らである。しかし，よ゙うあ道草を住いすぎてしまった，材料開発 に至らぬうちに矛を収めざるを得なくなってしまった。何故そう なった之問われれば，答えに笨するのであるが，レオロジーの分 野で研究を進めなければと思うことが次々に現れ，最後まで足を 洗えなかったとしか答えようがないように思われる。

レオロジーとレオ・オプティクスは，高分子の分野に限っても，

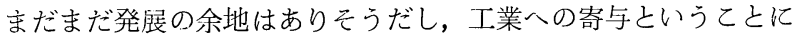
なれば，むしろこれからと言えそうな気访する。会員諸氏のご研 鑚を願ってやまない.

\section{文献}

1）堀尾正雄，小野木重治与，工化， 52，213，259，261，302, 303, 323 (1949) ; 53, 14, 66 (1950).

2) Oliver, D.A., Phil. Mag., 14, 318 (1932).

3) Horio, M., S. Onogi, J. Appl. Phys., 22, 977 (1951).

4) Horio, M., S. Onogi, ibid., 22, 971 (1951) ; 小野木重治, 安藤昭三, 山本 正, 工化, 57, 251 (1954); Onogi, S., K. Sasaguri, TAPPI, 44, 874 (1961).

5）例えば, Horio, M., S. Onogi, C. Nakayama, K. Yamamoto, J. Appl. Phys., 22, 966 (1951) ; Onogi, S., K. Ui, J. Colloid Sci., 11, 214 (1956).

6）小野木重治, 安藤昭三, 杉中一郎, 䋐維学会誌, 9, 617 (1953) ; 10, 32, 390 (1964).

7) Smith, T.L., J.D. Ferry, F.W. Schremp, J. Appl. Phys., 20, 144 (1949).

8）小野木重治, 平井英史, 寺崎秀雄, 近藤悌一郎, 工化, 61, 105 (1958).

9）平井英史, 近藤悌一郎, 寺崎秀雄, 小野木重治, 工化, 61, 596 (1958).

10) Onogi, S., I. Hamana, H. Hirai, J. Appl. Phys., 29, 1503 (1958).

11) Horio, M., T. Fujii, S. Onogi, J. Phys. Chem., 68, 778 (1964).

12) Onogi, S., T. Fujii, H. Kato, S. Ogihara, ibid., 68, 1598 (1964).

13) Onogi, S., T. Kobayashi, Y. Kojima, Y. Taniguchi, $J$. Appl. Polym. Sci., 7, 847 (1963).
14) Onogi, S., S. Kimura, T. Kato, T. Masuda, N. Miyanaga, J. Polym. Sci., C15, 381 (1966).

15）堀尾正雄, 小野木重治, 荻原定秀, 材料, 10, 350 (1961).

16）小野木重治, 材料試験, 8, 345 (1959).

17）升田利史郎，日本レオロジー学会誌，12，7 (1984).

18）松本孝芳, 同上, 13，167 (1985).

19) Onogi, S., T. Matsumoto, Polym. Eng. Rev., 1, 46 （1981）飞総合的飞報告されている.

20) Onogi, S., T. Masuda, T. Matsumoto, Trans. Soc. Rheol., 14, 275 (1970).

21) Matsumoto, T., Y. Segawa, Y. Warashina, S. Onogi, ibid., 17, 47 (1973).

22) Tobolsky, A.V., J.R. McLoughlin, J. Polym. Sci., 8, 543 (1952).

23) Ninomiya, K., H. Fujita, J. Colloid Sci., 12, 204 (1957).

24) Tobolsky, A.V., J. Am. Chem. Soc., 74, 3786 (1952); J. Appl. Phys., 27, 673 (1956).

25) Onogi, S., T. Masuda, K. Kitagawa, Macromolecules, 3, 109 (1970).

26) Onogi, S., D.A. Keedy, R.S. Stein, J. Polym. Sci., 50, S15 (1961).

27) Onogi, S., T. Asada, "Progress in Polymer Science, Japan", M. Imoto and S. Onogi ed., Kodansha, Tokyo (1971), pp. 261〜328 にまとめられている.

28) Fukui, Y., T. Asada, S. Onogi, Polym. J., 3, 100 (1972).

29) 浅田忠裕, 丸橋吉次, 小野木重治, 日本レオロジー学会誌, 3, 129 (1975).

30）浅田忠裕, 小野木重治, 日本化学繊維研究所講演集, 32 , 27 (1975).

31) Asada, T., S. Onogi, Polym. Eng. Rev., 3, 323 (1983); Onogi, S., T. Asada, Proc. 8th Intern. Congr. Rheology, 1, 127 (1980).

32） J.D. Ferry（根本紀夫訳), 日本レオロジー学会誌, 11, 163 (1983). 